\title{
PENGARUH PERCERAIAN PADA ANAK USIA DINI
}

\section{Srinahyanti*)}

Surel: sdzlaffer@gmail.com

\begin{abstract}
Divorce is the legal dissolution of a marriage relationship by a court and almost half of divorce happen in the first 10 years of marriage, it mean that children from divorced families are still at an early age. This means that daily interaction and communication between children with one of the parents will be reduced that can decreasing the attachment of the child to the parent and child trust affect against theirself. In addition, the child will be exposed to the fickle conditions, psychic tendencies negative emotions and aggressive behavior will appear on children as a victims of divorce.
\end{abstract}

Keywords: Parental Divorce, Early Childhood

\section{PENDAHULUAN}

Keluarga adalah unit terkecil dalam struktur masyarakat yang terbentuk dari sebuah pernikahan atau perkawinan. Pernikahan dan perkawinan terbentuk dari ikatan lahir bathin sepasang manusia yang bertujuan menciptakan kehidupan keluarga yang bahagia dan kekal berdasarkan Ketuhanan yang Maha Esa. Pernikahan ini juga menjadi satu satunya jalan yang dilegalkan dalam Undang Undang untuk memperoleh keturunan (anak).
Anak hadir dalam sebuah keluarga bagaikan kertas kosong. Anak belajar mengenai dirinya, bagaimana berprilaku dan berinteraksi pada lingkungan sekitar melalui keluarga, oleh karena itu keluarga juga disebut sebagai lingkungan yang pertama dan utama bagi seorang anak. Anak mendapatkan pengetahuan mengenai nilai-nilai kehidupan, pembentukan mental, psikologis dan belajar sosial dari kedua orang tuanya. 
Hal ini juga diungkapkan oleh Hurlock yang mengungkapkan bahwa tahun awal kehidupan anak, pendidikan dari orang tua dapat mempengaruhi prilaku dan sikap anak.

Kehidupan rumah tangga yang harmonis, rukun dan bersahaja diharapkan memberikan dampak positif bagi tumbuh dan kembang sosial dan emosi anak. Namun, rumah tangga dalam keluarga tidak selalu harmonis, terkadang konflik dapat muncul dari sebuah ketidakcocokan, bila berlarut akan berujung kepada perceraian.

Perceraian adalah salah satu kasus dalam keluarga di Indonesia yang mengalami peningkatan dari tahun ke tahun. Unit Statistik Badan Peradilan Umum dan Peradilan Agama menunjukkan perkara perceraian merupakan kelompok perkara terbesar dalam peradilan di Indonesia. $50 \%$ perkara perceraian, $33 \%$ perkara pidana dan $17 \%$ perkara perdata. Menurut Badan Kependudukan dan Keluarga Berencana (2013) Indonesia merupakan Negara dengan tingkat perceraian tertinggi di Asia Tenggara dan Mayoritas keluarga bercerai merupakan mereka yang usia pernikahan di bawah 10 tahun dan telah memilik anak (Anjani\&Suryanto 2006). Hal ini mengindikasikan bahwa pasangan yang bercerai memiliki anak yang berada pada tahapan usia dini.

Hal ini tentu menjadi sesuatu yang harus diperhatikan karena anak usia dini adalah masa paling penting dalam kehidupan manusia. Masa ini harusnya menjadi momen bagi kedua orang tua dengan bersama-sama memberikan rangsangan pendidikan agar anak siap secara fisik dan mental menghadapi fase-fase kehidupannya. Dalam masa ini anak juga sangat tergantung pada kedua orang tua dalam pemenuhan kebutuhan fisik dan psikisnya. Oleh karenanya perpisahan kedua orang tua bagi anak usia dini akan memberikan perubahan dan dampak bagi kehidupan anak selanjutnya.

\section{KAJIAN PUSTAKA}

Perceraian dalam Pasal 38 UU No.1 Tahun 1974 adalah putusnya perkawinan. Perkawinan disini adalah ikatan lahir bathin antara seorang laki-laki dan perempuan sebagai suami istri 
dengan tujuan membentuk keluarga (rumahtangga) yang bahagia dan kekal berdasarkan Ketuhanan yan Maha Esa. Jadi perceraian adalah putusnya hubungan keluarga (rumah tangga) antara suami dan istri.

Perceraian bukanlah sesuatu yang mudah dilakukan, terdapat prosedur yang harus dilalui oleh pasangan suami istri yang hendak bercerai. Proses dan hukum perceraian juga telah diatur oleh Undang-Undang Perkawinan begitupun alasan perceraian. Undang Undang No 1 Tahun 1974 Pasal 39 Ayat 2 dan PP No. 9 Tahun 1975 Pasal 19 menguraikan beberapa alasan hukum perceraian; Pertama: salah satu pihak berbuat zina, menjadi pemabuk, pemadat, penjudi, dan lain sebaginya yang sulit disembuhkan. Kedua: Salah satu pihak meninggalkan pihak lain selama dua tahun berturut-turut tanpa izin pihak lain dan tanpa alasan yang sah atau karena hal lain di luar kemampuannya. Ketiga; Salah satu pihak mendapatkan hukuman penjara 5 tahun atau hukuman yang lebih berat setelah perkawinan. Keempat, Salah satu pihak melakukan kekejaman atau penganiyayaan berat yang membahayakan pihak lain. Kelima, Salah satu pihak mendapat catatan badan atau penyakit dengan akibat tidak dapat menjalankan kewajiban sebagai suami istri. Keenam, Antara suami dan istri terus menerus terjadi perselisihan dan pertengkaran dan tidak ada harapan untuk hidup rukun lagi dalam rumah tangga.

Undang-undang No 20 Tahun 2003 menyatakan bahwa anak usia dini adalah anak yang berusia 0-6 tahun. Berdasarkan usia tersebut, anak usia dini dapat disebut sebagai anak pra sekolah atau berada pada jenjang/tingkat sekolah sebelum sekolah dasar. Pada masa ini anak lebih banyak menghabiskan waktu bersama kedua orangtuanya daripada lingkungan luar.

Masa usia dini disebut sebagi masa keemasan, dimana anak dengan mudah menerima stimulasi dan berbagai upaya pendidikan yang diberikan lingkungannya baik langsung maupun tidak langsung. Pada masa ini akan terjadi proses pematangan fungsi tubuh (fisik) dan psikologis anak, hingga anak siap 
melaksanakan

tugas

perkembangannya.

\section{HASIL DAN PEMBAHASAN}

Keluarga adalah lingkungan utama dan yang paling penting dalam pembentukan seorang anak. Anak belajar bagaimana merespon rangsangan dari luar dirinya melalui orang tua. Keluarga juga memberikan pengaruh terhadap pertumbuhan dan perkembangan anak dari anak lahir hingga ia mengenal lingkungan kedua dan ketiganya. Kemampuan anak berkembang melalui proses bimbingan dan percontohan dalam keluarga. Anak dapat belajar banyak aspek sosial, beragam norma dan nilai-nilai yang berkembang dalam keluarga dan masyarakat luar, serta dapat memberikan contoh penerapannya dalam kehidupan sehari-hari.

Salah satu harapan dalam keluarga adalah terciptanya kehidupan rumah tangga yang harmonis, dimana ayah dan ibu sebagai tiang keluarga bersinergi dan dapat bekerja sama dalam pembentukan jati diri anak serta bertanggung jawab terhadap proses tumbuh dan kembang anak, namun ada kalanya keharmonisan tidak lagi dapat dirasakan dikarenakan beberapa sebab sehingga terjadilah perceraian.

Sebuah interaksi dan situasi yang terjadi dalam keluarga, antar anggota keluarga dapat mempengaruhi anggota lainnya. Termasuk dalam kasus perceraian, perceraian adalah putusnya hubungan rumah tangga dan ikatan antara suami dan istri, bila terdapat anggota lain seperti anak, maka anak akan turut merasakan perubahan tersebut. Respon dan sikap anak terhadap perubahan tersebut dapat dipengaruhi oleh bagaimana sikap orang tua pada saat sebelum dan sesudah perceraian serta penyebab dari perceraian itu sendiri. Research and Statistics Division dalam Department of Justice Ministere de la Justice Canada memaparkan mengenai faktor yang mempengaruhi penyesuaian anak pasca perceraian antara lain; kharakteristik anak (gender dan usia anak saat perceraian), karakteristik keluarga (kedudukan sosial ekonomi, latar belakang budaya) dan karakteristik sosial (pernikahan kedua orangtua, 
konflik yang terjadi sebelum dan sesudah perceraian, support system hingga perubahan lingkungan)

Pada umumnya, Perceraian pada pasangan yang memiliki anak usia dini (0-6 tahun), hak asuh akan diberikan kepada ibu terkecuali bila ibu memiliki riwayat tindak kekerasan atau gangguan jiwa sehingga waktu yang dimiliki anak dengan ayah bisa jadi lebih minim daripada bersama ibu, terkadang anak juga harus mengalami penyesuaian terhadap lingkungan yang baru bila anak pindah ke rumah dan lingkungan yang berbeda. Penelitian Juth Wallerstein dan Joan Kelly pada 60 keluarga yang mengalami kasus perceraian di California juga menemukan bahwa anak pra sekolah (anak usia dini) akan lebih mengalami kesulitan dalam menyesuaikan diri menghadapi situasi yang baru. Pada anak usia dini, mereka memiliki kemampuan kognitif yang terbatas sehingga ia tidak bisa memahami dan memiliki keterampilan dalam menghadapi perubahan, akibatnya mereka akan lebih rentan terhadap masalah emosional dan kemampuan sosial. Hetherington

(2003) mengungkapkan bahwa anak pada keluarga yang bercerai beresiko tinggi mengalami masalah perkembangan psikologis, tingkah laku, sosial dan akademik dibandingkan dengan anak di keluarga utuh (tidak bercerai)

Pada usia anak 0-2 tahun, disebut sebagai masa awal kehidupan anak. Anak tidak memahami konsep perceraian dengan baik dan benar karena kemampuan kognitif yang masih sangat terbatas. Namun perubahan akibat yang dialami pada anak usia 0-2 tahun adalah tidak dapat tinggal bersama dengan kedua orang tua kandung. Pada usia ini anak membutuhkan kontak fisik dan psikis pada kedua orang tua atau dewasa sekitarnya untuk membangun kelekatan. Apriani mengungkapkan dalam penelitiannya bahwa kelekatan ibu memiliki hubungan yang signifikan terhadap kepercayaan diri anak taman kanakkanak.

Kelekatan antara anak dan orang tua akan menjadi dasar dalam membentuk kepercayaan diri anak bahwa anak merasa berharga, 
diinginkan dan dicintai. Kelekatan ini dihasilkan dari interaksi ataupun kontak harian dari kedua orang tua atau dewasa sekitarnya. Adanya perpisahan atau perceraian berarti anak kehilangan kontak dan interaksi harian dari salah satu orang tuanya. Hal ini menjadi permasalahan bila kedua orang tua tidak dapat bekerja sama maka anak akan kehilangan kelekatan dan memunculkan perasaan ketidakpercayaan pada dirinya sendiri.

Pada anak usia 2-5 tahun, anak mulai menyadari ketiadaan sosok salah satu orang tua mereka (ayah atau ibu). Pada masa ini kebutuhan akan perhatian, rasa kasih sayang sangat tinggi. Permasalahan yang mungkin timbul adalah kasih sayang yang tidak penuh dari kedua orang tua yang kemudian dapat mengakibatkan emosi negatif pada anak. yang berlebihan seperti rasa rendah diri,kecewa,marah dan sikap agresif.

Selain perilaku agresif akan muncul perasaan cemas dan rasa bersalah, American Academy of Childhood\& Adolescent Psychiatry menemukan banyak anak merasa bahwa merekalah penyebab konflik kedua orang tua mereka sehingga terjadi perpisahan pada keduanya sehingga dalam diri mereka timbul pearasaan rasa bersalah. Rasa bersalah (guilty feeling) yang dirasakan anak dapat berkembang menjadi kebencian pada dirinya sendiri dan ketakutan terhadap tindakannya sendiri dan orang lain. Bila orang tua tidak memberikan penjelasan yang tepat dan dapat dimengerti anak mengenai alasan perpisahan mereka maka emosi negatif tersebut akan mempengaruhi kehidupan sosial anak di masa yang akan datang dalam bentuk perilaku destruktif.

Perilaku destruktif ini merupakan tindakan menghancurkan, merusak dan memusnahkan, dapat dikatakan sebagai tindakan yang merugikan dirinya dan orang lain. Penelitian yang dilakukan STAI Citra Didaktika Jakarta dalam laman SDIT Al Inayah memaparkan perilaku destruktif yang timbul diantaranya $80 \%$ anak korban perceraian bangga menjadi orang yang ditakuti, $75 \%$ anak menantang orangtua dan guru, $70 \%$ sering memukul teman, bangga mendapat hukuman, sering mengutak atik 
barang hingga rusak, 55\% anak menganggu teman saat bermain bersama, melukai teman, membantah nasihat, menghina teman dan marah bila mendapat teguran, $50 \%$ bertengkar dengan teman, $45 \%$ melanggar tata tertib sekolah, mengolok teman, $40 \%$ membuat kegaduhan , 30\% merusak barang, tidak suka diatur, bermain sesuka hati dan marah bila diejek. Perilaku ini timbul karena kurangnya perhatian dari kedua orang tua. Perpisahan dapat menyebabkan intensitas pertemuan antara orang tua dan anak berkurang, ketika anak membutuhkan teman bicara dan bermain belum tentu ia dapatkan langsung bahkan bisa jadi anak tidak akan mendapatkannya bila kedua orang tua mengalami konflik yang belum selesai.

\section{Selain mempengaruhi} perilaku, emosi negatif yang didapatkan anak dari perceraian juga dapat mempengaruhi kesehatan tubuh anak. (Salovey, Rothman Detweiler, steward dalam Setyawan,2007) mengatakan bila seseorang mengalami emosi negatif maka kekebalan tubuhnya akan semakin menurun, demikian sebaliknya kalau seseorang mengalami emosi positif maka kekebalan tubuh akan semakin meningkat. Para psikolog di Universitas Carnegei, Mellon, Pennsylvania, Amerika Serikat (Watson,2017) melakukan penelitian mengenai dampak perceraian orang tua terhadap kesehatan anak mengungkapkan bahwa anak yang orang tuanya bercerai dan tidak berkomunikasi memiliki resiko terkena flu tiga kali lebih besar dibandingkan anak lain. Namun, resiko ini tidak berlaku bagi anak korban perceraian yang orang tuanya menjalin komunikasi dengan baik.

\section{SIMPULAN}

Dari pemaparan diatas, diketahui bahwa perceraian memiliki pengaruh terhadap tumbuh dan kembang anak, usia dini terutama berkaitan pada pengelolaan emosi, perilaku sosial serta kesehatan anak. Dampak tersebut dipengaruhi pula oleh sikap orang tua terhadap anak pasca perceraian. Dampak negatif yang timbul dapat diminimalisir dengan mencukupi kebutuhan fisik dan psikis anak. Mengutip teori 
Abraham Maslow dalam Wiyani (2014), setidaknya ada lima kebutuhan yakni kebutuhan fisiologis, kebutuhan akan rasa aman, kebutuhan akan rasa percaya diri, kebutuhan akan memiliki dan cinta, dan kebutuhan mengaktualisasi diri. Perpisahan suami dan istri tidak berarti perpisahan orang tua bagi anak-anaknya, anak memiliki hak untuk mendapatkan kasih sayang, perhatian, komunikasi serta waktu bersama orang tua mereka.

\section{DAFTAR PUSTAKA}

Akmalia, Nova dan Kasan, Tolib.

2012. Perilaku Destruktif pada Anak. Jakarta. Diakses dari http://sditalinayah.wordpress. com/2012/09/07 pada tanggal 22 November 2018.

Anjani, C. dan Suryanto.2006. Pola Penyesuaian Perkawinan pada Periode Awal. Insan. diakses dari https://journal.unair.ac.id pada tanggal 21 November 2018.
Apriani, Dinia Hetika.2016. Hubungan antara Kelekatan Anak pada Ibu dengan Rasa Percaya Diri pada Anak Taman Kanak-kanak. Tesis. Diunggah pada laman http://repository.upi.edu/2583 5 tanggal 22 November 2018.

BKKBN Online. 2013. Angka Perceraian di Indonesia tertinggi di Asia Pasifik. Badan Kependudukan dan Keluarga Berencana

Nasional. Diakses dari http://www.bllbn.go.id/viewb eri ta.aspx ?beritaID $=967$ pada tanggal 10 November 2018.

Galuzzo, Diana Marie. 2012. The Academic and Social Impact of Divorce on Early Childhood Students in School. Thesis. Massachusetss. University Boston. Diakses dari https://repository.library.nort heastern.edu/files/neu:1158/ pada tanggal 23 November 2018 
Hetherington, E.M. 2003. Social

Support and Adjustment of

Children in Divorced and

Remarried

Families.

Childhood. Diakses dari

https://journals.sagepub.com/

doi/10.1177/0907568203010

002007 pada tanggal 20

November 2018.

Hurlock, E.B. (2000). Perkembangan

Anak Jilid 1 Edisi Keenam.

Jakarta: Erlangga.

Muliana, dkk. 2016. Perkembangan

Perilaku Anak dari Keluarga

yang Bercerai di Kecamatan

Ulim Kabupaten Pidie Jaya.

Jurnal Ilmiah Mahasiswa

Pendidikan Anak Usia Dini.

M.S.W Wallerstein, Judith S. and Kelly, Joan B. 1975. The Effect of Parental

Divorce (Experiences of the

Preschool Child). Journal of The America $n$ Academy of Child and Adolescent Psychiatry. Diakses dari https://sciencedirect.com/scie nc e/article/pii/

Pada tanggal 29 November 2008.

Research and Statistics Division.1997. The Effects of Divorce on Children. Departement of Justice Ministere de la Justice. Canada.

Diakses dari https://www.justice.gc.ca pada tanggal 20 November 2018.

Watson, Sara Kiley.2017.Scientist Want to Know if Your Parents's Divorce is Making You Sick. Diakses dari https://www.popsci.com/divo rce -colds pada tanggal $20 \quad$ November 2018.

Wiyani, N.A. 2014. Mengelola dan Mengembangkan Kecerdasan Sosial dan Emosi Anak Usia Dini. Yogyakarta: Ar-Ruzz Media. 